\title{
PEMANFAATAN EKSTRAK DAUN TEMBAKAU (Nicotiana tabacum L) UNTUK MENGENDALIKAN ULAT GRAYAK (Spodoptera litura F) PADA TANAMAN SAWI (Brassica juncea L.) DI LAPANG
}

\author{
Maria Goreti Firma \\ SMA Pertanian Eko Ae, Kabupaten Ende
}

goretifirma@gmail.com

\begin{abstract}
Utilization of tobacco leaf extracts (Nicotiana tabacum L) to control Caterpillars grayak (Spodoptera litura F) on Mustard greens (Brassica juncea L.) plants in the field. This study aims to determine the effect of tobacco plant extracts on mortality of armyworm pests (Spodoptera litura F.) and determine the optimum concentration of tobacco leaf extracts on mortality of armyworm caterpillars on mustard plants in the field. The design used in this study was a Randomized Block Design (RBD) consisting of 5 treatments and 4 replications namely $\mathrm{T}_{1}: 175 \mathrm{ml} / \mathrm{L}$ concentration of tobacco leaf extract, $\mathrm{T}_{2}: 350 \mathrm{ml} / \mathrm{L}$ concentration of tobacco leaf extract $\mathrm{T}_{3}$ : Concentration of $525 \mathrm{ml} / \mathrm{L}$ tobacco leaf extract, $\mathrm{T}_{4}$ : Concentration of $700 \mathrm{ml} / \mathrm{L}$ tobacco leaf extract, $\mathrm{T}_{5}$ : Concentration of $875 \mathrm{ml} / \mathrm{L}$ of tobacco leaf extract. The observation variables in this study were pest mortality (\%), damage intensity (\%), plant fresh weight, and fresh weight per hectare (ton). The results showed that the concentration of tobacco leaf extracts significantly affected the mortality of Spodoptera litura F. At the concentration of $\mathrm{T}_{5}$ treatment $(875 \mathrm{ml})$ were the lowest damage, pest mortality, fresh weight of the mustard plant, and fresh weight per hectare of was $9.75 \%, 88 \%, 109.25$ gr, and 27.31 tons respectively.
\end{abstract}

Keywords: Mustard greens, Spodoptera litura F, Tobacco leaf

\section{PENDAHULUAN}

Tanaman Sawi (Brassica juncea L.) merupakan salah satu jenis sayuran yang banyak dikonsumsi oleh masyarakat, jenis sayuran ini mempunyai prospek yang baik untuk dikembangkan karena mempunyai kandungan gizi yang cukup tinggi. Keadaan alam Indonesia memungkinkan dilakukannya pembudidayaan berbagai jenis tanaman sayuran, baik yang lokal maupun yang berasal dari luar negeri. Hal tersebut menyebabkan Indonesia ditinjau dari aspek klimatologis sangat potensial dalam usaha bisnis sayursayuran (Sutanto, 2002).

Menurut data Statistik Nasional, total produksi sawi Nasional tahun 2013 mencapai 635.728 ton, sedangkan pada tahun 2014 mengalami penurunan total produksi sebesar 597.675 ton (BPS Nasional, 2014). Produksi sawi Propinsi 
NTT pada tahun 2013 mencapai 5.042 ton, sementara pada tahun 2014 produksi sawi mencapai 6.120 ton (BPS NTT, 2014). Berdasarkan data Dinas Pertanian Kabupaten Ende tahun 2013 produktivitas sawi pada tahun 2013 sebesar 945,5 kw/ha, sedangkan pada tahun 2014 produktivitas sawi hanya mencapai $495 \mathrm{kw} / \mathrm{ha}$ sehingga mengalami penurunan produktivitas sebesar $450.5 \mathrm{kw} / \mathrm{ha}$ (BPS Kabupaten Ende, 2014). Salah satu faktor yang menyebabkan penurunan produktivitas tanaman sawi adalah serangan hama ulat grayak (Spodoptera litura F.) dengan tingkat serangan kurang lebih $70 \%$.

Pengendalian yang dilakukan petani untuk mengendalikan hama ulat grayak, umumnya menggunakan pestisida sintetik. Pengendalian ini dilakukan secara terus menerus sehingga memberikan dampak negatif terhadap komponen ekosistem seperti terbunuhnya musuh alami terjadinya resulgensi dan resistensi hama serta pencemaran lingkungan karena residu yang ditinggalkan (Moeksan, 2000). Upaya dalam mengatasi masalah tersebut, maka diperlukan upaya pengendalian yang ramah lingkungan terhadap ekosistem, salah satunya yaitu pemanfaatan tumbuhan sebagai pestisida nabati. Pestisida nabati adalah pestisida yang berasal dari tumbuhan alami yang dapat dimanfaatkan untuk mengendalikan hama pada tanaman, salah satu tumbuhan yang mempunyai potensi sebagai pestisida nabati dalam pengendalian hama adalah tembakau (Hasyim, 2010).

Tembakau (Nicotiana tabacum L.) merupakan salah satu jenis tanaman yang dapat digunakan sebagai pestisida alami. Bagian yang sering digunakan adalah bagian daun dan batang alkaloid yang terkandung dalam nikotin adalah bahan organik yang mengandung nitrogen sebagai bahan dari sistem heterosiklik. Alkaloid yang bersifat basa yang mengandung satu atau lebih atom nitrogen, biasanya sebagai gabungan dari system siklik dan pada umunya mengandung oksigen. Senyawa alkaloid banyak terkandung dalam akar, biji, kayu, maupun daun dari tumbuhan. Peran alkaloid bagi tumbuhan sebagai zat racun yang melindungi tumbuhan dari gangguan serangga. Alkaloid lebih cepat larut, sehingga bahan aktif yang maasuk ke dalam tubuh serangga melalui kutikula dan trakea dapat langsung merusak fungsi sel serangga sehigga menyebabkan mortalitas. Daun tembakau kering mengandung 2-8\% nikotin. Tanaman tembakau yang dapat dijadikan sebagai pestisida organik karena kandungan nikotinnya yang tinggi mampu mengusir hama pada tanaman, sehingga tembakau bukan hanya digunakan untuk konsumsi rokok semata, tetapi bisa diolah menjadi pestisida organik yang berfungsi sebagai penolak, insektisida, fungisida, dan akarisida. Sebagai racun kontak, racun perut, dan racun pernapasan. Kandungan nikotin yang terdapat pada bagian daun tembakau dapat diekstraksi dan dimanfaatkan sebagai pestisida alami karena dapat menjadi racun syaraf yang potensial. Ekstrak nikotin tembakau sangat baik untuk mengendalikan serangga ulat. Hasil penelitian Ahmad (2015) pada pengujian skala laboratorium dengan pemanfaatan 
Firma: Pemanfaatan ekstrak daun tembakau (Nicotiana tabacum L) untuk mengendalikan ulat grayak (Spodoptera litura F)

ekstrak tembakau pada hama ulat grayak dengan konsentrasi $350 \mathrm{ml}$, menyebabkan mortalitas hama ulat grayak sebesar 95\%. Penelitian ini bertujuan untuk mengetahui pengaruh dan konsentrasi optimum ekstrak daun tembakau terhadap mortalitas ulat grayak pada tanaman sawi di lapang

\section{METODE PENELITIAN}

Penelitian ini dilaksanakan di kebun percobaan Fakultas Pertanian Universitas Flores, Kelurahan Lokoboko, Kecamatan Ndona, Kabupaten Ende. Waktu penelitian dari bulan oktober sampai bulan November 2015. Bahan-bahan yang digunakan dalam penelitian ini adalah daun tembakau segar, deterjen, air dan tanaman sawi varietas tosakan. Alat-alat yang digunakan dalam penelitian ini adalah ember, saringan, alat semprot, timbangan, dan alat tulis. Penelitian ini menggunakan Rancangan Acak Kelompok (RAK) yang terdiri atas 5 perlakuan konsentrasi ekstrak daun tembakau yaitu : $\mathrm{T}_{1}$ : Konsentrasi 175 $\mathrm{ml} / \mathrm{L}$ ekstrak daun tembakau, $\mathrm{T}_{2}$ : Konsentrasi $350 \mathrm{ml} / \mathrm{L}$ ekstrak daun tembakau, $\mathrm{T}_{3}$ : Konsentrasi $525 \mathrm{ml} / \mathrm{L}$ ekstrak daun tembakau, $\mathrm{T}_{4}$ : Konsentrasi $700 \mathrm{ml} / \mathrm{L}$ ekstrak daun tembakau, $\mathrm{T}_{5}$ : Konsentasi $875 \mathrm{ml} / \mathrm{L}$ ekstrak daun tembakau. Setiap perlakuan diulang sebanyak 4 kali sehingga terdapat 20 satuan percobaan.

\section{HASIL DAN PEMBAHASAN}

Hasil analisis sidik ragam menunjukan bahwa ekstrak daun tembakau berpengaruh sangat nyata terhadap mortalitas hama ulat grayak (Spodoptera litura F.) pada tanaman sawi di lapang (Tabel 4.1).

Tabel 4.1. Pengaruh ekstrak daun tembakau terhadap mortalitas hama ulat grayak (Spodoptera litura F.)

\begin{tabular}{|c|c|}
\hline Perlakuan & Mortalitas (\%) \\
\hline $\mathrm{T}_{1}$ & $61,00 \mathrm{e}$ \\
\hline $\mathrm{T}_{2}$ & $70,00 \mathrm{~d}$ \\
\hline $\mathrm{T}_{3}$ & $74,00 \mathrm{c}$ \\
\hline $\mathrm{T}_{4}$ & $79,00 \mathrm{~b}$ \\
\hline $\mathrm{T}_{5}$ & $88,00 \mathrm{a}$ \\
\hline BNT & 0,94 \\
\hline
\end{tabular}

Keterangan: angka angka yang diikuti oleh huruf yang sama pada kolom yang sama berarti tidak berbeda nyata pada uji bnt taraf 5\%. Data itranformasikan dengan arscin.

Hasil pengamatan pada Tabel 4.1 menunjukan bahwa perlakuan ekstrak daun tembakau pada setiap konsentrasi yang diberikan dapat meningkatkan mortalitas ulat grayak dari $\mathrm{T} 1$ ke $\mathrm{T} 2$ sebesar 12,85\%, T2 ke T3 sebesar
5,40\%, T3 ke T4 sebesar 6,32\%, T4 ke T5 sebesar 10,22\%. Mortalitas hama ulat grayak Spodoptera litura F. Disebabkan karena ekstrak tembakau mengandung nikotin yang mengandung senyawa alkaloid bekerja lebih efektif dalam 
menghambat perkembangan ulat sehingga menyebabkan mortalitas. Nikotin adalah alkaloid yang terdapat pada daun tembakau, berperan sebagai racun kontak terhadap beberapa ulat salah satunya adalah golongan Lepidoptera dan serangga pengisap yang bertubuh lunak. Selain berfungsi sebagai racun kontak nikotin juga berfungsi sebagai penolak (repelan) kehadiran serangga yang disebabkan bau yang menyengat, antifidan atau mencegah serangga memakan tanaman, merusak perkembangan telur, larva, dan pupa, menghambat reproduksi bagi serangga betina dan mengacaukan sistem hormon di dalam tubuh serangga (Soenandar dkk., 2010). Berdasarkan hasil tersebut maka hipotesis pertama (1) terbukti, karena semakin tinggi konsentrasi sehingga kandunga bahan aktif semakin banyak sehingga menyebabkan sistem reproduksi ulat grayak terganggu dan merusak perkembangan ulat hingga mortalitas.

Perlakuan konsentrasi ekstrak daun tembakau $875 \mathrm{ml} / \mathrm{L} \quad\left(\mathrm{T}_{5}\right)$ menyebabkan mortalitas hama ulat grayak S. litura F. paling tinggi sebesar
$88 \%$ dibandingkan perlakuan konsentrasi lainnya. Hal ini disebabkan, karena pada konsentrasi tersebut jumlah senyawa bahan aktif lebih banyak sehingga racun yang mengenai kulit larva $S$. litura F. bekerja lebih efektif dalam menghambat perkembangan larva dan menyebabkan mortalitas menjadi lebih tinggi. Hal ini disebabkan karena ekstrak daun tembakau mengandung nikotin yang mengandung senyawa alkaloid. Senyawa alkaloid adalah bahan organik yang mengandung nitrogen sebagai bahan dari sistem heterosiklik.

Perlakuan ekstrak daun tembakau $175 \mathrm{ml} / \mathrm{L}\left(\mathrm{T}_{1}\right)$ menyebabkan mortalitas larva ulat grayak $S$. litura $\mathrm{F}$. paling rendah sebesar 61\%. Hal ini disebabkan karena jumlah bahan aktif saponin pada ekstrak tersebut lebih sedikit $(61,25)$ sehingga lebih kecil dalam menghambat perkembangan larva yang berdampak pada mortalitas yang rendah. Hasil analisis sidik ragam menunjukan bahwa ekstrak daun tembakau berpengaruh sangat nyata terhadap intensitas serangan hama ulat Grayak Spodoptera litura F. pada tanaman sawi di lapang (tabel 4.2).

Tabel 4.2. Pengaruh Ekstrak Daun Tembakau terhadap Intensitas Serangan Spodoptera litura F.

\begin{tabular}{cc}
\hline Perlakuan & Intensitas serangan $(\%)$ \\
\hline $\mathrm{T}_{1}$ & \\
$\mathrm{~T}_{2}$ & $53,25 \mathrm{a}$ \\
$\mathrm{T}_{3}$ & $42,75 \mathrm{~b}$ \\
$\mathrm{~T}_{4}$ & $33,25 \mathrm{c}$ \\
$\mathrm{T}_{5}$ & $17,75 \mathrm{~d}$ \\
$\mathrm{BNT}$ & $9,75 \mathrm{e}$ \\
\hline
\end{tabular}


Firma: Pemanfaatan ekstrak daun tembakau (Nicotiana tabacum L) untuk mengendalikan ulat grayak (Spodoptera litura F)

Keterangan: angka angka yang diikuti oleh huruf yang sama pada kolom yang sama berarti tidak berbeda nyata pada uji bnt taraf 5\%. Data itranformasikan dengan arscin

Hasil menunjukan bahwa perlakuan ekstrak daun tembakau pada setiap konsentrasi yang diberikan dapat menekan serangan ulat grayak pada tiap konsentrasi perlakuan dari $\mathrm{T}_{1}$ ke $\mathrm{T}_{2}$ sebesar $19,71 \%, \mathrm{~T}_{2}$ ke $\mathrm{T}_{3}$ sebesar $22,22 \%, \mathrm{~T}_{3}$ ke $\mathrm{T}_{4}$ sebesar $46,61 \%, \mathrm{~T}_{4} \mathrm{ke}$ $\mathrm{T}_{5}$ sebesar $45,07 \%$. menyebabkan nilai intensitas serangan larva $S$. litura F. yang berbeda-beda akibat mortalitas yang berbeda pula. Hal ini disebabkan karena konsentrasi ekstrak tembakau yang ditingkatkan mengandung senyawa alkaloid lebih banyak pula sehingga bekerja lebih efektif dalam menghambat perkembangan ulat sehingga menekan tingkat serangannya. Nikotin adalah alkaloid yang terdapat pada daun tembakau, merupakan racun kontak terhadap beberapa ulat salah satunya adalah golongan Lepidoptera dan serangga pengisap yang bertubuh lunak. Selain berfungsi sebagai racun kontak nikotin juga berfungsi sebagai repelan atau menolak kehadiran serangga yang disebabkan bau yang menyengat, antifidan atau mencegah serangga memakan tanaman, merusak perkembangan telur, larva,dan pupa, menghambat reproduksi bagi serangga betina, mengacaukan sistem hormon di dalam tubuh serangga, (Soenandar, dkk, 2010).

Perlakuan konsentrasi ekstrak daun tembakau $875 \quad \mathrm{ml} / \mathrm{L} \quad\left(\mathrm{T}_{5}\right)$ menyebabkan intensitas serangan hama ulat grayak S. litura F. paling rendah sebesar 9,75\% dibandingkan perlakuan konsentrasi lainnya. Hal ini disebabkan karena pada konsentrasi tersebut jumlah senyawa bahan aktif lebih banyak alkaloid 28\% (245) saponin sebesar 7\% $(61,25)$ lebih banyak, sehingga racun yang mengenai kulit larva S. litura F. bekerja lebih efektif dalam menghambat perkembangan larva dan menyebabkan mortalitas menjadi lebih tinggi sehingga intensitas serangan menjadi rendah. Pestisida nabati bersifat mengusir dan mengurangi nafsu makan hama sehingga memerlukan proses yang lambat. Intensitas serangan yang rendah pada perlakuan ini juga disebabkan karena ekstrak daun tembakau selain mengandung senyawa alkaloid juga mengandung senyawa saponin yang merusak sistem syaraf larva sehingga menyebabkan nafsu makan menjadi hilang dan pelan-pelan intensitas serangan dan jumlah populasi hama menjadi berkurang. Perlakuan ekstrak daun tembakau $175 \mathrm{ml} / \mathrm{L} \quad\left(\mathrm{T}_{1}\right)$ menyebabkan intensitas serangan larva paling tinggi sebesar 53,25\%. Hal ini disebabkan karena jumlah bahan aktif alkaloid dan saponin yang terkandung pada ekstrak tersebut lebih sedikit dimana alkaloid yang terkandung sebesar $49 \mathrm{ml} / \mathrm{L}$, sedangkan saponin yang terkandung sebesar 12,25 ml/L sehingga lebih kecil dalam menghambat perkembangan larva yang berdampak pada mortalitas yang rendah sehingga intensitas serangan menjadi tinggi. Hal 
ini disebabkan pada konsentrasi ekstrak tembakau mengandung senyawa saponin lebih sedikit sehingga nafsu makan serangga menjadi besar pada tanaman sawi yang diikuti dengan peningkatan populasi hama.

Hasil analisis sidik ragam menunjukan bahwa ekstrak daun tembakau berpengaruh sangat nyata terhadap intensitas serangan hama ulat Grayak Spodoptera litura F. pada tanaman sawi di lapang (tabel 4.3). Hasil tersebut menunjukan bahwa perlakuan ekstrak daun tembakau pada setiap konsentrasi yang berbeda menunjukan rataan perbedaan berat segar tanaman sawi pada tiap perlakuan dari $\mathrm{T}_{1}$ ke $\mathrm{T}_{2}$ sebesar $17,52 \%, \mathrm{~T}_{2}$ ke $\mathrm{T}_{3}$ sebesar 8,51\%, $\mathrm{T}_{3} \mathrm{ke}^{\mathrm{T}} \mathrm{T}_{4}$ sebesar $7,24 \%, \mathrm{~T}_{4}$ ke $\mathrm{T}_{5}$ sebesar $5,85 \%$. dan berat segar perhektar yang berbeda pula yakni $\mathrm{T}_{1}$ ke $\mathrm{T}_{2}$ sebesar $16,16 \%, \mathrm{~T}_{2}$ ke $\mathrm{T}_{3}$ sebesar $9,30 \%, \mathrm{~T}_{3}$ ke $\mathrm{T}_{4}$ sebesar $7,79 \%, \mathrm{~T}_{4}$ ke $\mathrm{T}_{5}$ sebesar
6,22\%. Hal ini disebabkan karena peningkatan konsentrasi ekstrak tembakau sehingga meningkatkan nikotin yang mengandung senyawa alkaloid bekerja lebih efektif dalam menghambat perkembangan larva dan menyebabkan mortalitas. Nikotin adalah alkaloid yang terdapat pada daun tembakau, merupakan racun kontak terhadap beberapa ulat salah satunya adalah golongan Lepidoptera dan serangga pengisap yang bertubuh lunak. Selain berfungsi sebagai racun kontak nikotin juga berfungsi sebagai repelan atau menolak kehadiran serangga yang disebabkan bau yang menyengat, antifidan atau mencegah serangga memakan tanaman, merusak perkembangan telur, larva,dan pupa, menghambat reproduksi bagi serangga betina, mengacaukan sistem hormon didalam tubuh serangga, (Soenandar,dkk, 2010).

Tabel 4.3. Pengaruh Ekstrak Daun Tembakau Terhadap Berat Segar pertanaman

\begin{tabular}{ccc} 
Perlakuan & $\begin{array}{c}\text { Berat Segar Pertanaman } \\
\text { (gram) }\end{array}$ & $\begin{array}{c}\text { Berat segar } \\
\text { (ton/ha) }\end{array}$ \\
\hline $\mathrm{T}_{1}$ & $72,0 \mathrm{e}$ & $18,00 \mathrm{e}$ \\
$\mathrm{T}_{2}$ & $87.3 \mathrm{~d}$ & $21.82 \mathrm{~d}$ \\
$\mathrm{~T}_{3}$ & $95.42 \mathrm{c}$ & $23.85 \mathrm{c}$ \\
$\mathrm{T}_{4}$ & $102.85 \mathrm{~b}$ & $25.71 \mathrm{~b}$ \\
$\mathrm{~T}_{5}$ & $109.25 \mathrm{a}$ & $27.31 \mathrm{a}$ \\
\hline BNT & 4.90 & 0,55
\end{tabular}

Keterangan: angka angka yang diikuti oleh huruf yang sama pada kolom yang sama berarti tidak berbeda nyata pada uji bnt taraf 5\%. Data ditranformasikan dengan arscin.

Perlakuan ekstrak daun tembakau 175 $\mathrm{ml} / \mathrm{L}\left(\mathrm{T}_{1}\right)$ menyebabkan berat segar sawi pertanaman dan perhektar paling rendah sebesar 72 gram dan 18 ton. Hal ini disebabkan karena jumlah bahan aktif pada ekstrak tersebut lebih sedikit sehingga lebih kecil dalam menghambat perkembangan larva yang berdampak pada mortalitas yang rendah sehingga 
Firma: Pemanfaatan ekstrak daun tembakau (Nicotiana tabacum L) untuk mengendalikan ulat grayak (Spodoptera litura F)

intensitas serangan menjadi tinggi dan penurunan berat segar tanaman.

\section{KESIMPULAN}

Berdasarkan tujuan, maka dapat disimpulkan hal-hal sebagai berikut:

1. Efektivitas estrak daun tembakau berpengaruh nyata pada tingkat mortalitas hama ulat grayak pada tanaman sawi dimana tiap perlakuan menunjukan rataan yang berbeda dimana mortalitas sebesar $8,69 \%$, intensitas serangan sebesar $33,40 \%$, berat segar pertanaman sebesar $9,78 \%$ dan berat segar tanaman sawi perhektar sebesar $9,86 \%$

2. Konsentrasi optimal ekstrak daun tembakau adalah $875 \mathrm{ml} / \mathrm{L}\left(\mathrm{T}_{5}\right)$ dengan mortalitas sebesar $88 \%$ intensitas kerusakan 9,75\%, berat segar sawi pertanaman sebesar 109,25 gr dan berat segar sawi perhektar sebesar 27,31 ton.

\section{DAFTAR PUSTAKA}

Abdullah, Ahmad Soedarmanto. 2003. Budidaya Tembakau. Jakarta : CV Yasaguna.

Anonim. 2011. Tanaman Inang Ulat Grayak. Kanisius, Yogyakarta.

Badan Pusat Statistik Provinsi NTT. 2008. Publikasi NTT Dalam Angka 2008, Kupang.

BPS dan Direkorat Jendral Hortikultura. 2013. Statistik Pertanian (Agricultura Statisties).2008.DepertemenPertan ainRepublikIndonesia.Jakarta.(http
://www.bps.go.id/booklet/Boklet_fe bruari_2014 pdf). Disidir 21 februari 2014.

Cahyono, Bambang. 2001. Tembakau, Budi Daya Dan Analisis Tani. Yogyakarta : Kanisius.

Data Dinas Pertanian Kabupaten Ende. 2012. Luas Panen, Produksi dan Rata-Rata Menurun. Kantor Pusat Statistik Kabupaten Ende.

Dbph direktorat jenderal bina produksi hortikultura. 2007. Perkembangan Luas Panen Sayuran. 1996-2005. http://www.deptan.go.id.(diakses tanggal 01 Januari 2014).

Dian Purnama Sari. 2013. Pengaruh Limbah Tembakau Terhadap Mortalitas Ulat Grayak (Spodoptera Litura F.) skripsi Jurusan Hama dan Penyakit Tumbuhan Fakultas Pertanian Universitas Jember.

Doli, Oppung. 2013. Pengertian Isolasi dan Ekstraksi Pengertian Isolasi dan Ekstraksi _ Klik BBM Blog Pengertian.htm .Diakses 15 noveember 2015.

Gomez, K.A., Gomes, A.A 2007. Prosedur Statistik Untuk Penelitian Pertanian.

Haidar, M. H., L. Nurdiana., dan R. Amalia. 2012. Pemanfaatan Ekstrak Nikotin Limbah Puntung Rokok. 
Harapap, L. 2009. Pengamatan OPT pada Tanaman Kubis di Saree Kec.Lemba Selawah Kab. Aceh Besar. Skripsi S1. Jurusan Agroteknologi, Fakultas Pertanian, Universitas Syiah Kuala Darussalam, Banda Aceh.

Hartati, Ahmad. 2015. Uji Efektivitas Ekstrak Daun Tembakau Terhadap Ulat Grayak, Uniflor:Skripsi. Ende.

Haryanto, E. 2001. Sawi dan Selada, Penebar Swadaya, Jakarta.

Hasyim. 2010 Jenis Pestisida Nabati Dan Kegunaannya http://www.deptan.go.id diakses 01 September 2014.

Magdalena. 2008. Keragaman Ukuran dan Warna Spodoptera litura F. pada Tanaman Sawi (Brassica juncea L.) di Berbagai Ketinggian Tempat. Skripsi. Bogor (ID): Fakultas Pertanian, Institut Pertanian Bogor.

Moekasan. 2000. Pengendalian Hama Terpadu Dan Implementasinya. Indonesia.

Natawigena. 1989. Pestisida Dan Kegunaannya. Bandung: CV Armico.

Pramono, D. 2005. Seri Pengelolahan Hama Tebu secara Terpadu. Jilid 1 dan 2. PT. Dioma, Malang 219 dan 225 hal.
Rukmana. 2007. Bertanam Sawi. Kanisius. Yogyakarta. 48 hal.

Soenandar, M, Aeni, M. N., dan Raharjo,A. 2010 Petunjuk Praktis Membuat Pestisida Organik . PT Agromedia pustaka. Tangerang.

Suhenry,sri.2013.pengambilan nikotin dari batang tembakau. http://repository.upnyk.a $\quad$ 53/ $1 /$ sri suhenry exergi jun1 2U10.p df di akses pada tanggal 17 november 2015 .

Sutanto. 2002. Budidaya Sawi. Balai Penelitian Tanaman Hortikultura. Pasuruan, Jawa Timur.

Yuphy. Blogspot.Com/2011/11/Budidaya Tanaman Tembakau dan pemanfaatannya Diakses 01 September 2011. 